\title{
Explaining continuity and change in post- communist central European welfare states
}

\begin{abstract}
This paper develops a theoretical framework for explaining instances of reform and continuity in various social policy areas in central and eastern European countries, focusing on Hungary and Poland. Drawing on the welfare state literature on the region, I outline various pressures for reform and pressures for continuity that influence the propensity for change, but I argue that it is the defining cleavages between the parties and the characteristics of central and eastern European party systems, interacted with the various types of pressures on both, that explains why we see dramatic reform in some cases and historic continuity in others.
\end{abstract}

Keywords: welfare state, change, reform, redistribution

\section{Introduction}

The economic and political transformations that took place in central and eastern European countries suggest that there was an opportunity truly to recreate post-communist welfare states compatible with a market economy and re-emerged democracy. There have already been some important contributions regarding the diversity of central and east European welfare states. ${ }^{1}$ Based on these authors' findings and my own earlier empirical work, this paper begins with the understanding that modern welfare states across the region do differ significantly from each other. In addition to the diversity of central and east European welfare states, an interesting debate has developed in the literature regarding the degree of transformation that such welfare states have undergone. One set of literature argues that there have been dramatic and revolutionary changes in them, but other literature examines the importance of historical, institutional and policy legacies for enforcing continuity on post-communist welfare states. Close analysis reveals indeed that, in some social policy areas in some countries, dramatic reforms and changes have taken place in the region's welfare states while, in other

1 Nick Manning (2004) 'Diversity and Change in Pre-Accession Central and Eastern Europe Since 1989' Journal of European Social Policy 14(3), August: 211-232; Martin Rhodes and Maarten Keune (2006) 'EMU and welfare states in East Central Europe' in Enlarging the Euro Area: External Empowerment and Domestic Transformation in East Central Europe New York: Oxford University Press, p. 376; Mitchell Orenstein and Martine Haas (2005) 'Globalization and the Future of Welfare States in the Postcommunist East Central Europe' in Miguel Glatzer and Dietrich Rueschemeyer (Eds.) Globalization and the Future of the Welfare State Pittsburgh: University of Pittsburgh Press, p. 130-152; Dorothee Bohle and Béla Greskovits (2007) 'Neoliberalism, embedded neoliberalism and neocorporatism: Towards transnational capitalism in Central-Eastern Europe' West European Politics 30(3): 443-466; Tomasz Inglot (2008) Welfare States in East Central Europe, 1919-2004 New York: Cambridge University Press. 
social policy areas in other countries, there has been a surprising degree of continuity and stability during the transition.

This leads to the question: what determines the degree of change and stability in post-communist welfare states? I aim to explore the explanatory factors behind the diverse welfare state reform paths (in three policy areas) so as to understand the reasons for their diversity and, most importantly, explain the instances of change and continuity in the policy areas. I argue that many possible explanatory factors may constitute a set of pressures for reform or, alternatively, pressures for continuity but it is the action and interaction between political actors that is essential for explaining the diversity of welfare state structures. Given that reform proposals have emerged in each policy area in each country, I argue that the role of political actors is essential for understanding both the instances of continuity and those of reform.

In this article, I present a theoretical framework for explaining change and consistency in central and east European welfare states, beginning the empirical work by looking at Hungary and Poland. The reason for beginning this analysis with Hungary and Poland is that I can control for the magnitude of total welfare spending, pre-transfer inequality, similar international influences and similar post-communist political swings between left- and right-wing governments. In the next section, I review the relevant literature and outline the pressures for reform and continuity summarised therein, following which I summarise the differences in party systems that influence welfare state reform. Finally, I specify the explanatory framework that I propose for understanding change and continuity in central and eastern European welfare states, which will be tested in future research.

\section{Assessing pressures for reform and pressures for continuity}

The economic and political transition that has been taking place in central and eastern European countries since 1989 has brought many forms of radical and systemic change. Consequently, there has been a potential for dramatic change in the social policy that accompanied the new democratic political system and the market-based economic system. Much of the literature on welfare states in central and eastern Europe refers to the dramatic and revolutionary change of these welfare states, even if reforms occurred after some delay. ${ }^{2}$ From this literature, it is clear that there existed multiple sources of pressure for the reform of the prevailing systems of social policy in transition.

Pressure for the reform of welfare states in transition resulted from:

1. the collapse of previous social support systems (price subsidies; employmentbased social benefits through state-owned firms)

2 Guy Standing (1996) 'Social Protection in Central and Eastern Europe: a Tale of Slipping Anchors and Torn Safety Nets," in Gosta Esping-Andersen (Ed.) Welfare States in Transition: National Adaptations in Global Economies London: United Nations Research Institute for Social Development, pp. 225-255; Hans-Jürgen Wagener (2002) 'The Welfare State in Transition Economies and Accession to the EU' West European Politics 25(2): 152-174; Katharina Müller (1999) The Political Economy of Pension Reform in Central-Eastern Europe Studies in Comparative Economic Systems, Cheltenham: Edward Elgar; Orenstein and Haas 'Globalization and the Future of Welfare States in Postcommunist East Central Europe'. 
2. the need to address transformed social challenges during transition (unemployment; rising poverty with reduced price subsidies),

3. the constraints posed by fiscal deficits

4. pressure from international actors (i.e. the World Bank; the EU).

Given these pressures, it seems that significant reforms to the welfare state were possible, if not inevitable. During this time of 'extraordinary politics', ${ }^{3}$ the societies and electorates in central and eastern European countries accepted radical changes in many policy areas, even ones that brought about difficulties during transition. The social supports that existed during the communist regime (price supports; firm-based social services) were no longer compatible in a market-based economy with privatelyowned firms. So, reforms were necessary not only to meet new social needs and complement the new economic system, but also to reduce fiscal budget deficits in many countries.

In contrast to the pressures for reform, there is a substantial literature emphasising the historical continuity and path dependence of the welfare states of the Višegrad countries. This literature examines the importance of institutional and historical legacies for enforcing the continuity of post-communist welfare states with a path dependent understanding of welfare state development. ${ }^{4}$ These authors argue thoroughly that historical legacies have clearly shaped future reform options and have led to a surprising continuity in central and eastern European welfare states. Post-communist central and eastern Europe could have been expected to provide just the context for radical reformed approaches to welfare, but many argue that the role of historical legacies has dominated. Inglot argues that:

Certain clearly discernible patterns of social policy making within each country tend to persist, survive regime change, and often reemerge in similar configurations in different historical periods. ${ }^{5}$

The transition in central and eastern European countries was a time when extreme change was acceptable and expected, although it did become:

A rare historic event of regime change that involves reproduction of the welfare state. ${ }^{6}$

The historical continuity of central and eastern European welfare states suggests that there was also pressure for continuity. The pressures for continuity resulted from:

3 Leszek Balcerowicz (1995) Socialism, Capitalism Transformation Budapest: CEU Press).

4 Inglot Welfare States in East Central Europe, 1919-2004; Béla Tomka (2004) Welfare in East and West: Hungarian Social Security in an International Comparison, 1918-1990 Jahrbuch für Wirtschaftsgeschichte 5, Berlin: Akademie-Verlag; Alfio Cerami (2006) Social Policy in Central and Eastern Europe: The Emergence of a New European Welfare Regime Region, Nation, Europa Bd. 43 (Berlin: Lit, 2006).

5 Inglot, op. cit, p. 2.

6 Ibid. p. 296. 
1. Veto players who represent present-day beneficiaries that defend their benefits under the current system. This is related to the 'power resource' model of welfare state reform, which observes that entrenched interests block reform. Historical legacies could be said to have created 'politically constructed property rights', meaning that citizens felt entitled to these benefits and blocked any reform that threatened them ${ }^{7}$

2. Institutional legacies that constrain change where new central and eastern European welfare states are recalibrated versions of past institutional configurations ${ }^{8}$ or are reformed only in 'layers'. ${ }^{9}$ Past institutional arrangements create dynamics that make the sudden and complete reform of institutions difficult. Transformative change is possible, but only over an extended period of time

3. Societal perceptions of the past that form expectations in society about the way a welfare state should be. These perceptions (both positive and negative) of past policy and history influence public opinion and, therefore, electoral outcomes and voters' expectations of political actors. ${ }^{10}$

As outlined above, there are two sets of literature that investigate post-communist central European welfare states and reach opposing conclusions about the degree of change in social policy. Notably, the authors that identify dramatic change base their findings on policy areas in countries that have indeed experienced dramatic change (for example: many aspects of the Hungarian and Polish pension reforms; Polish family allowance; the Slovak reforms of $2003 / 4 ; \ldots$. . In contrast, the authors that find surprising continuity and path dependence in welfare states are focusing on policy areas where continuity can be observed (for example: Hungarian family allowance; the Czech pensions system; Polish benefits and pensions for agriculture and favoured sectors; ...).

In each country in different policy areas, there have been meaningful and even dramatic reforms. In addition, there is much evidence that historical legacies have a significant influence on the welfare reform process. Therefore, we must determine the mechanisms behind the influence both of pressures for continuity and pressures for reform in order to understand why significant change occurs in some policy areas and some countries, but not in others.

Importantly, proposals have been made in all Višegrad countries for the drastic reform of many (if not all) dimensions of the welfare state. These proposals have been debated in parliaments and have often been decisive in electoral outcomes for political

7 Herman Schwartz (2001) 'Round up the usual suspects! Globalization, Domestic Politics and Welfare State Change' in Paul Pierson (Ed.) The New Politics of the Welfare State Oxford: Oxford University Press, p. 31.

8 Inglot, op. cit; László Bruszt and David Charles Stark (1998) Postsocialist Pathways: Transforming Politics and Property in East Central Europe Cambridge Studies in Comparative Politics, Cambridge: Cambridge University Press.

9 Kathleen Thelen (2003) 'How institutions evolve: Insights from comparative-historical analysis' in James Mahoney and Dietrich Rueschemeyer (Eds.) Comparative Historical Analysis in the Social Sciences Cambridge Studies in Comparative Politics, Cambridge: Cambridge University Press, pp. 208-240.

10 Dorothee Bohle and Béla Greskovits (2010) 'Combating Poverty and Inequality in East-Central Europe' Journal of Democracy (forthcoming). 
parties. Some of these proposals were adopted and substantial reforms set in motion. In order for reform to occur, political and/or social actors must have been involved in designing, gaining support for and implementing reform plans. Some reforms occurred and were later 'undone', creating a return to the previous approach. Other proposals were rejected and led to continuity in the welfare state. In order for continuity to occur, political actors had also to choose: here, not to reform. Even in cases of non-reform, the questions and possibilities of reform have been part of the political debate in almost every policy area in each central and eastern European country. Given that reform proposals existed in each of the countries, and in each of the policy areas, a less obvious, but very important, point for my research is that: instances of non-reform also required active measures from political actors (i.e. non-reform also requires agency).

Given that varying degrees of both pressures for reform and pressures for continuity exist(ed) in different policy areas in different countries, I argue that domestic political actors mediate between these pressures and determine the degree of reform or stability in each policy area. The pressures form the context for reform, but political actors are the mediators and are, therefore, an important (and often neglected) variable in determining the degree of change or continuity in welfare states. In other words, pressure for reform is a necessary, but not sufficient, condition for reform; while pressure for continuity is a necessary, but not sufficient, condition for stability. It is political actors, more specifically political parties, that decide how to respond to the various pressures and which consequently determine the degree and type of reform. The role of politics is largely neglected in the literature on central and eastern European welfare states and, even when it is recognised, there is a lack of a systematic evaluation of how politics affects welfare state reforms. For this reason, evaluating the role of political actors in welfare state reform in central and eastern Europe is one of the primary aims of my research and will be the focus of the following section.

\section{Role of political actors and party systems}

In the welfare state literature on central and eastern Europe, there is a limited group of authors who have recognised the importance of political actors in understanding welfare state outcomes. The first type focuses on the presence or absence of veto players: i.e. bureaucrats or interest groups that seek to block reforms. ${ }^{11}$ This literature focuses primarily on explaining the lack of reform (or the significant delays in reforms) by identifying the actors that have blocked reforms (parties, politicians, trade unions or other social actors). Similar to the historical legacy literature, this literature does not

11 Michael Cain and Aleksander Surdej (1999) 'Transitional Politics or Public Choice? Evaluating Stalled Pension Reforms in Poland' in Linda J. Cook, Mitchell A. Orenstein and Marilyn Rueschemeyer (Eds.) Left Parties and Social Policy in Postcommunist Europe Boulder: Westview Press, pp. 145-174; Jerzy Hausner (2001) 'Security though Diversity: Conditions for Successful Reform of the Pension System in Poland' in János Kornai, Stephan Haggard and Robert R Kaufman (Eds.) Reforming the State: Fiscal and Welfare Reform in Post-Socialist Countries New York: Cambridge University Press, pp. 210-234; Titio Boeri (2003) 'Social Policy Models in Transition: Why Are They So Different From One Another?' in Robert Holzmann, Mitchell Orenstein and Michal Rutkowski (Eds.) Pension Reform in Europe: Process and Progress Washington, D.C: The World Bank. 
explain why reform does occur at specific points in time; it can only explain continuity, the lack of reform, or the limited degree of reform. Brown performs a thorough analysis of the social policy decisions of political actors in early transition, and concludes that early decisions restricted future welfare state reform possibilities, but she does not explain how change could occur at later stages of transition. ${ }^{12}$ Other literature that recognises the importance of the political actors is more limited in its scope, evaluating either one policy area or one country (such as early retirement, or Polish pensions reform). ${ }^{13}$ This literature analyses political actors in a single country and policy area without explaining why actions were different in other policy areas or other countries. Consequently, the findings from this literature, while informative, are not generalisable to the broader central and eastern European welfare state context.

In this literature, the role of electoral politics and the importance of political parties and party systems have been virtually ignored. Assuming that these new democracies have a sufficiently functioning democratic system, then the electoral pressures of different groups of voters should have significant influence over the welfare reform process. ${ }^{14}$ In a comparison of welfare states in Latin America, east Asia and eastern Europe, Haggard and Kaufman conclude that one of the decisive determinants in central and eastern European welfare states was 'powerful electoral and interest group pressures,' but they do not specify the nature and interaction of these electoral and interest group pressures and how they vary from country to country. ${ }^{15}$ Orenstein argues that democracy matters as regards post-communist welfare state outcomes, demonstrating that countries that are rated as more democratic have higher welfare state spending, and suggests that 'democratic political pressure' and veto actors significantly affect welfare state outcomes, but does not invoke any political mechanism. Both Orenstein and Cook argue that the level of democracy influences the size of post-communist welfare states, based on contrasting most of the states in the former Soviet Union with states that are new member states of the European Union. This very recent literature emphasises the importance of 'democratic political pressure', or electoral pressure, but does not reconcile the relationship of these pressures with the other pressures outlined earlier, nor do they evaluate how electoral pressures vary across countries and across policy areas. This is the goal of my research.

12 Dana Brown (2005) The new politics of welfare in post-socialist Central Eastern Europe MIT $\mathrm{PhD}$ thesis, available at: $\mathrm{http}: / /$ dspace.mit.edu/handle/1721.1/33682? show=full [last accessed on 4 July 2010].

13 Pieter Vanhuysse (2006) Divide and Pacify: Strategic Social Policies and Political Protests in Post-Communist Democracies Budapest: Central European University Press; Cain and Surdej, op. cit.

14 I assume a sufficient degree of agreement between electoral opinion and political actions, but my argument does not depend on the direction of the causality. Whether the electorate determines actions or political actors, or political actors shape the opinions of the electorate, is an interesting question for another research project.

15 Stephan Haggard and Robert R. Kaufman (2008) Development, Democracy and Welfare States: Latin America, East Asia and Eastern Europe Princeton: Princeton University Press, p. 360 . 
Political parties form the most important political actor for my research as they are the primary actors that mediate the various pressures for reform and continuity. Other social actors (trade unions; non-governmental organisations) play a secondary role and will be highlighted where relevant, but my investigation of politics in welfare state reform in central and eastern Europe focuses on parties and party systems.

To understand the role of political actors in welfare state reform, it is important to understand:

1. the positions of the major parties towards social policy reform (varies by policy area)

2. the nature of cleavages ${ }^{16}$ between the parties

3. interaction between the parties (i.e. coalition formation)

4. the structure of the party system.

A more qualitative analysis of the positions of the major parties and their interactions will be outlined in a later section. Here, I summarise the evaluation of party positions and party systems on the social policy dimension, particularly relying on the work of Kitschelt et al and Rohrschneider and Whitefield. ${ }^{17}$

In their analysis of post-communist party systems, Kitschelt et al ${ }^{18}$ investigate four dimensions important for understanding party systems:

1. issue salience (How much does an issue matter?)

2. programmatic crystallisation (Do all agree where the parties stand on issues?)

3. polarisation (How spread out are the parties in the issue space?)

4. systematic asymmetries (Does a party's self-identification vary from how others identify it?).

The authors investigate these dimensions through surveys among politicians across many issue spaces, conducted in 1994. I focus on their findings for the social security dimension. Table 1 presents the scores in the social security dimension on the four characteristics of party systems for Hungary and Poland compared to the mean score for all countries (Bulgaria, Czech Republic, Hungary and Poland).

16 I use Whitefield's definition of party cleavages: 'Political cleavages are conceived of here as strongly structured and persistent lines of salient social and ideological division among politically important actors. This definition requires social division but is not limited to it, involves social difference to connect not only to varied views of the world but also to political competition, and says that people who are thus divided matter to political outcomes.' Stephen Whitefield (2002) 'Political Cleavages and Post-Communist Politics' Annual Review of Political Science 5: 181.

17 Herbert Kitschelt et al. (1999) Post-Communist Party Systems: Competition, Representation and Inter-Party Cooperation Cambridge University Press; Robert Rohrschneider and Stephen Whitefield (2009) 'Understanding Cleavages in Party Systems: Issue Position and Issue Salience in 13 Post-Communist Democracies' Comparative Political Studies 42(2), February: 280-313.

18 Kitschelt et al. (1999), op. cit. 
Table 1 - Characteristic of party competition in Poland and Hungary (from Kitschelt et al 1999)

\begin{tabular}{|l|c|c|c|}
\hline Score on social security dimension & Poland & Hungary & $\begin{array}{c}\text { Mean (all } \\
\text { countries) }\end{array}$ \\
\hline Salience of issue (low = 1; high = 5) & 4.4 & 4.5 & 4.5 \\
\hline $\begin{array}{l}\text { Programmatic diffuseness } \\
\text { (standard deviation on 20 point scale) }\end{array}$ & 3.1 & 2.9 & 3.2 \\
\hline $\begin{array}{l}\text { Spread/polarisation of parties } \\
\text { (standard deviation on 20 point scale) }\end{array}$ & 3.5 & 1.9 & 3.0 \\
\hline $\begin{array}{l}\text { Asymmetry of parties' issue positions } \\
\text { (Low if the within-party placement matches } \\
\text { outsiders' placement of the party in the issue } \\
\text { space) }\end{array}$ & 5 & 15 & 8.8 \\
\hline
\end{tabular}

Source: Kitschelt et al (1999): 157-180.

Clearly, the social security issue is highly salient for politicians in both Poland and Hungary, but the parties are notably more polarised on social security issues in Poland than they are in Hungary. Interpreting the programmatic diffuseness and the asymmetry indicators together then, for Poland, it is apparent that the parties have well-defined positions on social security and all actors agree on this placement. For Hungary, the high level of asymmetry suggests that politicians disagree about where other parties stand on social security. Combining this with low polarisation, Kitschelt et al conclude that valence competition is dominant in Hungary. ${ }^{19}$ This means that the political parties are competing less on the types of welfare policies that should be introduced and more on the competence of their own party to introduce them.

Furthermore, Rohrschneider and Whitefield (2009) compare the importance of different conflict dimensions for party competition. Using expert surveys conducted in 2003-2004, they rate the importance of conflict dimensions from 1 (most important) to 5 (least important). In Hungary, the most important dimensions for party competition are nationalism (score: 2.1), followed by the welfare state (3.3) and the communist legacy (3.5). In Poland, the most important dimensions for party competition are the welfare state (2.2), religiosity (2.8) and nationalism (3.6).

At this time, I am also focusing only on the welfare state dimension, given its salience in both countries and its obvious relevance to the research project. In future research, however, I plan to incorporate the cleavages along the dimensions of religious and nationalist/communist legacies, which may also be important in understanding 
certain dimensions of welfare state reform (such as the position of the pro-religious parties on family benefit policy). ${ }^{20}$

In Poland, the left- and right-wing parties that have formed governing coalitions differ substantially from each other concerning their position on the welfare scale. ${ }^{21}$ Using the seven-point scale presented by Rohrschneider and Whitefield (2009), where 1 implies support for welfare and 7 opposition to welfare provision, the parties of the left-wing coalitions (Democratic Left Alliance (SLD); Polish People's Party (PSL)) are rated between 2 and 4, while the parties in the right-wing coalitions (Freedom Union (UW); Civic Platform (PO)) are positioned between 6 and 7. This suggests significant differences in policy positions between the parties on welfare state policies, which must be negotiated in reforms, and corresponds to the higher degree of polarisation in Poland, as suggested earlier.

In Hungary, the difference between party positions is low on the welfare scale, with the major parties in left-wing coalitions (Hungarian Socialist Party (MSZP)) scoring at approximately 3.8; while the right-wing coalition (Hungarian Democratic Forum (MDF); Hungarian Civic Union-Alliance of Young Democrats (Fidesz)) scoring at 4.6. This again suggests a very low degree of polarisation between the major Hungarian parties on the welfare dimension. ${ }^{22}$ Once again, given that parties in Hungary tend not to be class-based, the low difference between parties on the welfare scale and the high salience of welfare issues further supports the argument that, in Hungary, politicians exercise valence competition on the welfare state dimension.

Hungary has been characterised by relatively stable political actors throughout the transition. In Poland, however, there has been a high degree of volatility of the parties during the transition, with many parties entering and leaving the political sphere. However, the findings of Kitschelt et al (1999) for early transition, and Rohrschneider and Whitefield (2009) for later transition, confirm that the polarisation of parties on the welfare state dimension has been consistently high. In fact, often when parties have disappeared, new parties have occupied a similar space on the welfare dimension (to be argued in a different paper). Therefore, I maintain that, despite the high volatility, the defining characteristics of the Polish party system can be analysed.

\section{Towards an integrated theoretical framework}

In this article, I have outlined the types of pressures for reform and continuity, the importance of incorporating politics into explanations of welfare states in central and eastern Europe, and proposed the dimensions of politics that I think could explain different welfare state outcomes, party types and party systems. Other authors also argue

20 It is also important to keep in mind that the communist legacy scale may capture ideological and socio-economic factors by dividing winners and losers in the communist takeover and the post-communist transition. Zsolt Enyedi (2008): 'The Social and Attitudinal Basis of Political Parties: Cleavage Politics Revisited' European Review 16: 298).

21 This assumes the relative stability of the positions of parties on the welfare dimension during transition.

22 There is, however, a much higher degree of polarisation on the nationalist or communist legacy scale, which will be investigated in future research. 
that both historical legacies and transitional politics matter, but do not evaluate or systematise the interaction of these factors. ${ }^{23}$ However, I aim to go beyond the argument that 'everything matters' and to outline a theoretical framework for how historical legacies and politics interact to produce reform or stability in welfare states in the region. Figure 1 outlines the theoretical schema with which I propose to explain the interaction between the various determinants of welfare state outcomes.

I show in Figure 1 my argument that pressures for reform and continuity are mediated by political actors in order to determine the welfare state outcome. For example, in the case of pressures for reform from international actors, it is clear that welfare reforms were not a major priority for international advisors in central and east European countries until the mid- to late-1990s, given the many challenges of the transition. Early in the transition, international actors had:

Little to say on the social-sector restructuring that was to become such a large part of post communist transformation. ${ }^{24}$

The consequence was that central and east European countries made many reforms to the welfare system and national politicians had significant freedom in choosing how to reform (or not to reform) the welfare state. ${ }^{25}$ When more significant reforms finally occurred, in some of the countries, in some policy areas, the welfare reforms were often overseen and advised by the World Bank, which generally favoured a liberal social welfare model. ${ }^{26}$ However, countries varied in the degree to which they followed the World Bank's advice and in the methods of implementation. ${ }^{27}$ Domestic political actors clearly responded to the pressures in different ways, which issue will be explored further in my continuing research.

23 Cain and Surdej (1999) op. cit; Phineas Baxandall (2003) 'Postcommunist unemployment politics: historical legacies and the curious acceptance of job loss' in Grzegorz Ekiert and Stephen E Hanson (Eds.) Capitalism and Democracy in Central and Eastern Europe: Assessing the Legacy of Communist Rule Cambridge: Cambridge University Press, pp. 248-288; Mitchell Orenstein (2008) 'Postcommunist Welfare States' Journal of Democracy 19(4), October: $80-94$.

24 Orenstein (2008) op. cit: 85.

25 Louise Fox (2003) Safety Nets in Transition Economies: A Primer The World Bank, available at: http://go.worldbank.org/5WUUT4VPT0.

26 János Mátyás Kovács (2002) 'Approaching the EU - and Reaching the US? Rival Narratives on Transforming Welfare Regimes in East-Central Europe' West European Politics 25(2): 175-204..

27 Wagener (2002) op. cit. p. 171. 
Figure 1 - Explanatory schema for welfare state change and continuity

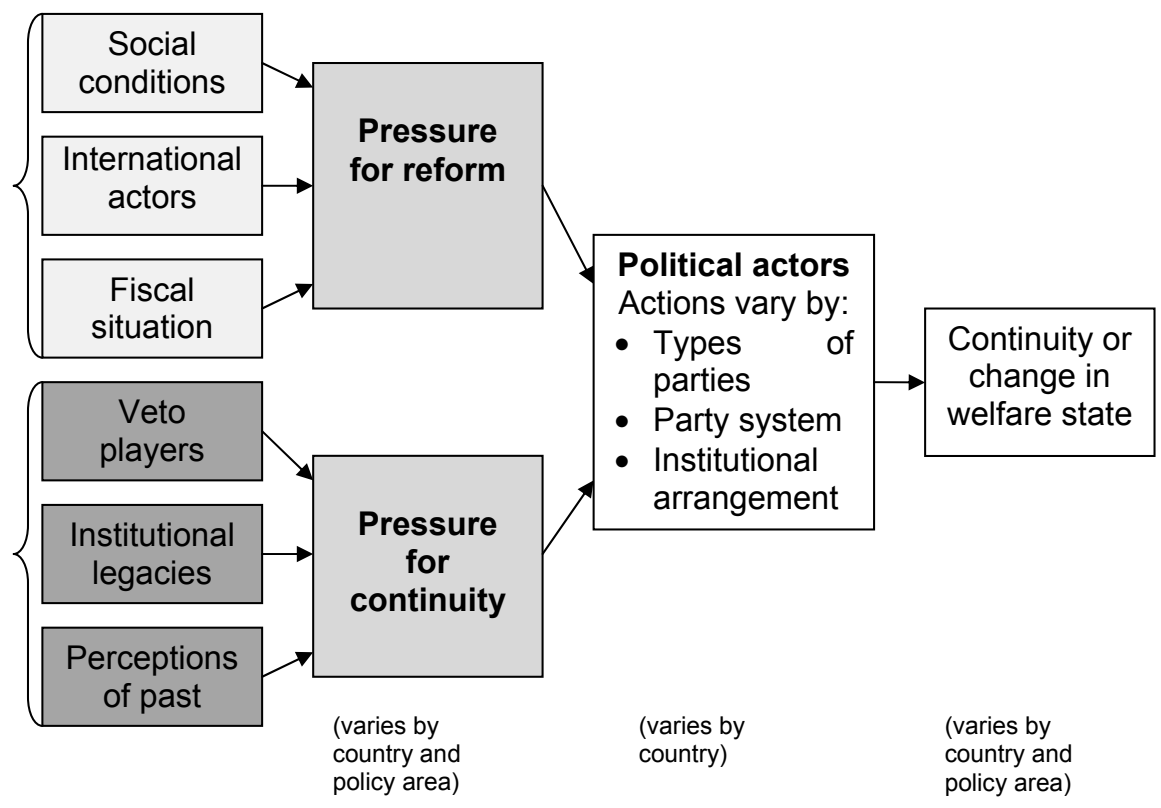

Various combinations of pressures are likely to provide incentives for different actions by politicians, leading to different welfare state outcomes. Less obviously, similar pressures may have led to different political action, depending on the type of parties and the characteristics of the party system. The interaction of these two dimensions offers a way of systematically analysing welfare state outcomes in central and eastern Europe that has the potential to explain variations across countries as well as variations across policy areas within the same country.

Much of the literature on central and eastern European welfare states has attempted to fit these transformed welfare states into existing welfare state typologies, based on Esping-Andersen. ${ }^{28}$ The above theoretical framework suggests the need to begin to analyse welfare states in central and eastern Europe as 'patchwork welfare states' where we do not a priori assume that the same welfare logic functions across all policy areas. Given that the primary goal is to explain instances of reform and stability in welfare states in central and eastern Europe, I will analyse the effects across multiple policy areas. In particular, I argue that the degree of change varies significantly between countries and between policy areas within each country. Further, the differences between the degrees of change in different policy areas can be understood through the interaction of pressures for reform and continuity, interacted with the characteristics of the party system applying in each country. Press.. 
The initial hypotheses for the influence of party types and the characteristics of the party system on welfare state outcomes, which will be tested in my future empirical research, are:

a) Cross-class parties increase the likelihood of support for welfare policies benefiting middle income households.

Cross-class parties have a unique role in welfare state reform, because they rely heavily on the support of middle income households. For policy areas where the status quo clearly benefits middle income households, cross-class parties will promote a continuity of welfare state policy. On the other hand, if there is a policy area where the status quo clearly does not benefit middle income households, crossclass parties will advocate reform in that policy area.

b) Party cleavages (i.e. high polarisation) along distributional or welfare state dimensions increase the likelihood of reform.

Polarisation along welfare dimensions implies that at least some parties have preferences that deviate from the status quo. Strong cleavages on the welfare dimension also increase the likelihood that debates regarding reform will emerge in more policy areas. Polarisation of actors is therefore a necessary (but not a sufficient) condition for reform. In order for reform to occur and have lasting effects, there is also a need for some compromise between the parties which balances their divergent preferences. Holding pressures for reform and continuity constant, a country with a polarised system is likely to see more substantial reform over time.

c) Coalitions between parties that support the same policy outcomes based on preferences for different dimensions of that policy increase the likelihood of reform (because diverse political actors support the reform).

Given that most policies are multi-dimensional, unlikely coalitions may be formed that can lead to welfare state change (for example, a coalition for reform in the area of family policy between parties with the goal of targeting and reducing spending and other parties that promote traditional family values). This implies that a polarisation of party positions along the welfare dimension does not always imply conflicts in reform preferences (based on the multi-dimensional nature of policies). ${ }^{29}$ This, once again, suggests that pressures for reform and continuity interact with political factors to create different reform outcomes across countries and across policy areas within a single country.

\section{Conclusions}

Based on previous research, we may observe the very different reform trajectories of welfare states in post-communist central and eastern Europe. A review of the literature suggests the need to reconcile two opposing literature themes and to develop an understanding of the relationship between historical factors and political agency in welfare state reform in central and eastern Europe.

29 Silja Häusermann (2008) Beyond Continuity: Coalitional dynamics as drivers of gradual transformative policy change in Continental pension politics presented at the ESPAnet Doctoral Researcher Workshop 'The Politics of Recalibration: Welfare Reforms in the Wider Europe', Forli, Italy, p. 11. 
My research demonstrates the interaction of pressures for reform and continuity and the role of political parties and party systems. The context of the Polish reform seems to be highly polarised political actors representing different constituencies seeking compromises in each policy area. The Hungarian political parties, in contrast to the Polish ones, seem to represent similar socio-economic constituencies, leading to a policy that favours middle income households and to continuity in any policy area that benefits this group.

This article proposes an explanatory framework for the nature of the interaction between political parties that serves as a possible explanation for the different reform outcomes. The hypotheses outlined here will later be tested in multiple policy areas, including:

1. social assistance and family benefit reforms

2. policies towards the non-employed - evaluating unemployment and early pension together

3. old age pension reform.

My research so far demonstrates that actor-based and historical arguments are likely to be most fruitful when explored simultaneously, also taking into account the interaction of these two explanations. 